\title{
LENIN IS DEAD, His Museum is Finnish - The Lenin Museum IN TAMPERE
}

\section{Aimo Minkkinen}

In 1995 there was a disastrous earthquake in Sahalin which destroyed the town of Neftekamsk totally. Only Lenin's statue was saved and it now stands on even ground. Symbolic? When Finland became independent in December 1917, its civil war was won by the Whites aided by German troops. Lenin's Finnish connections were no longer officially remembered. The situation changed completely after the Second World War. The Lenin Museum in Tampere was founded on January 20th, 1946 by the Friendship Society of Finland and the Soviet Union (now called The Finland-Russia Society).

It was the people of the city of Tampere who originally took the initiative in establishing the Lenin Museum. As early as the 1920s the students in the workers' institute discovered they were studying in the very Workers' Hall where Lenin had pledged to a delegation of townspeople his willingness to further the cause Finnish independence.

Now it is the world's last Lenin Museum. To be accurate, we must say "the world's last museum of Lenin's entire life's work». All Lenin Museums as such in Russia and other former socialist countries have closed their doors, last among them being the Central Lenin Museum in Moscow, in November 1993. All that remains are exhi- bitions devoted to particular periods in Lenin's life. His childhood is remembered in Ulyanovsk, in his home town, and his last years in the village of Gorky, near Moscow, where he died in 1924.

The collapse of socialist countries has made the Tampere Lenin Museum a curiosity. The Lenin Museum has now expanded its task to cover an entire historical period: the era of Soviet socialism. The museum has undertaken to preserve, exhibit and research the objects, documents and symbols of the Soviet era.

The Finnish journalist Simopekka Virkkula writes about the Lenin Museum: «A Canadian couple are fascinated. Eyes shining, they display the finds they have 


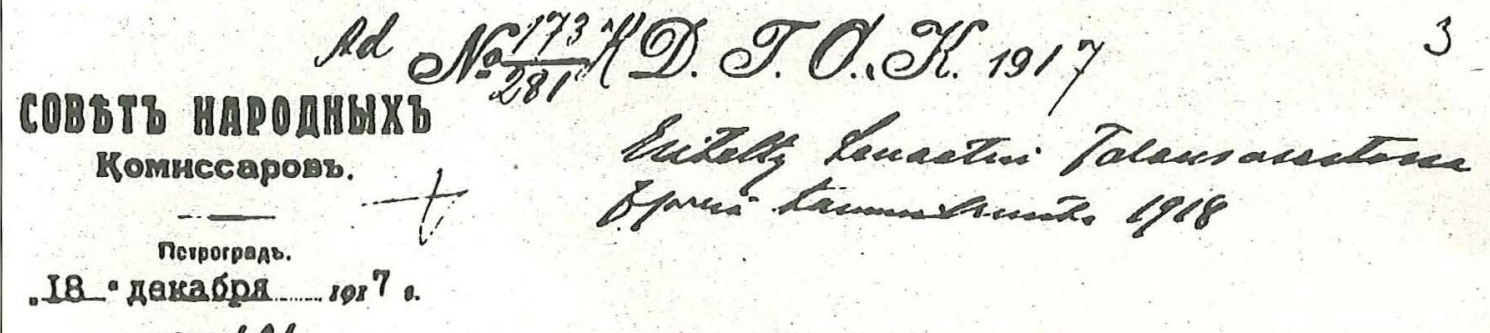
25. 101

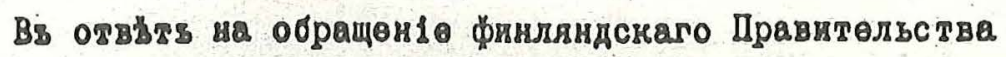

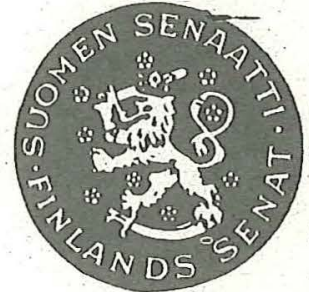

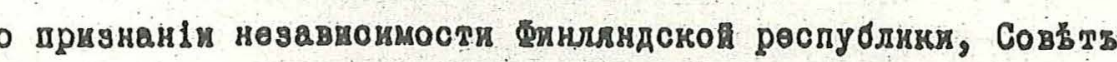

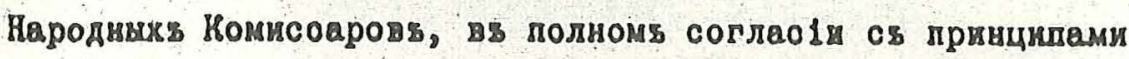

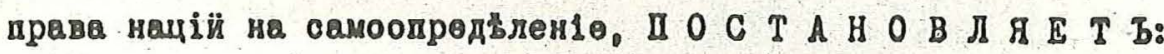

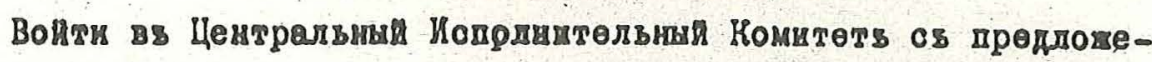
Hens:

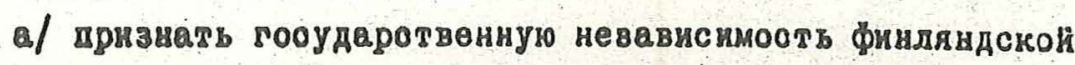
Рестублики

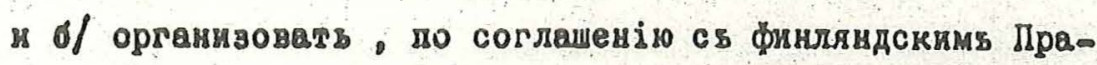

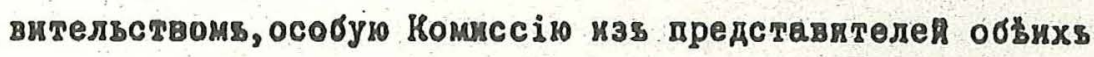

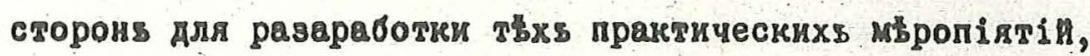

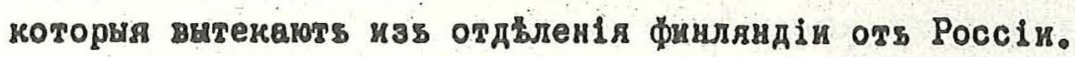

\section{Предсвдатель Совьта Народнвж5}

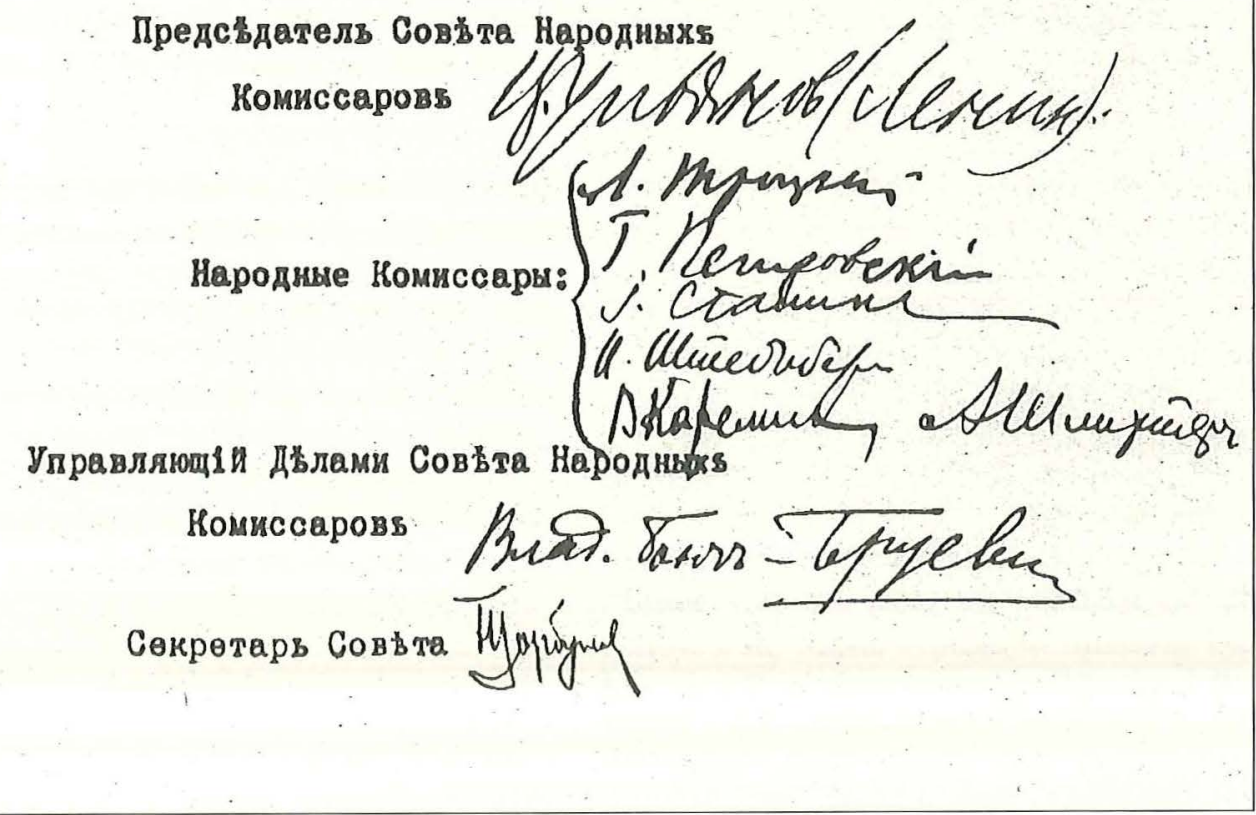

The decree of the Soviet government of the independence of Finland signed by V. I. Lenin in December 1917. 
made in the museum shop; among their gifts are a handful of Red Army badges. I myself have lingered over the bookshelves. Where else could one still find books like B. Ponomaryov's Marxism-Leninism, A living and Effective Creed?»

Last year people from 68 different countries all over the world passed through its doors. Many travellers are impressed to hear that the Museum is housed in the Workers' Hall where the Russian Social Democratic Party held two secret conferences in the years 1905 and 1906 which Lenin attended and chaired. It was in this very room that Lenin and Stalin met each other for the first time during the 1905 conference in Tampere.

Stalin had heard of Lenin, and because of the size of his reputation imagined he would be a tall man. But when he saw Lenin he was disappointed because he was not so tall. Although few records of the conference remain, it is known that the Bolshevilks were given free of charge the use of the rooms, which at the time housed Finland's first workers' college, and that they held a further session in the following year.

In 1906 Lenin pledged to the workers of Tampere that after the revolution succeeded in Russia his party would honour the nation's right to self-determination. In accordance with this principle Finland would be granted independence, should the Finnish people so desire. This pledge was made in the same hall which is today the Lenin Museum.

One of the most intriguing exhibits of the Lenin Museum is a copy of a December 1917 document of the Soviet government, which granted Finland independence from the Tsarist empire. The recognition of the independence of Fin- land, signed by Lenin, Stalin, Trotsky and other members of the first soviet Council of People's Commissars on December 31, 1917, was not a decision imposed on Lenin, but rather a logical application of the national policy Lenin had adopted. This policy was based on the idea of a nation's right to self-determination, thus it was logical that the Finnish people should themselves have the right to decide their own fate. Lenin said of the independence of Finland: "It is impossible not to acknowledge that which already exists. The very fact itself demands its own recognition.»

Documents containing Lenin's writings in the Lenin Museum reveal that Lenin held Finland and the Finnish people in very high esteem and thought that Finland was one of the most highly developed democracies in existence at that time. He had come to rely on Finnish support in the struggle against the Tsar, the common enemy.

Indeed, Lenin spent the better part of two years in Finland following the collapse of the 1905 Revolution. This common enemy, the Tsarist regime, had a unifying influence among the Finnish fighters for national freedom as it had among Russian revolutionaries. Lenin had several times hidden from his enemies in Finland and Tampere, and later he employed several Finns as bodyguards, highly valuing their trustworthiness. He had many Finnish friends and was considered to be a general friend of Finland. Lenin used Finland frequently in his writings as an example of the national question. More than 340 of Lenin's speeches, articles and other documents concerning Finland and the Finns can be studied in the Lenin Museum.

Between 1905 and 1907 Lenin partici- 
AIMO MINKKINEN

134

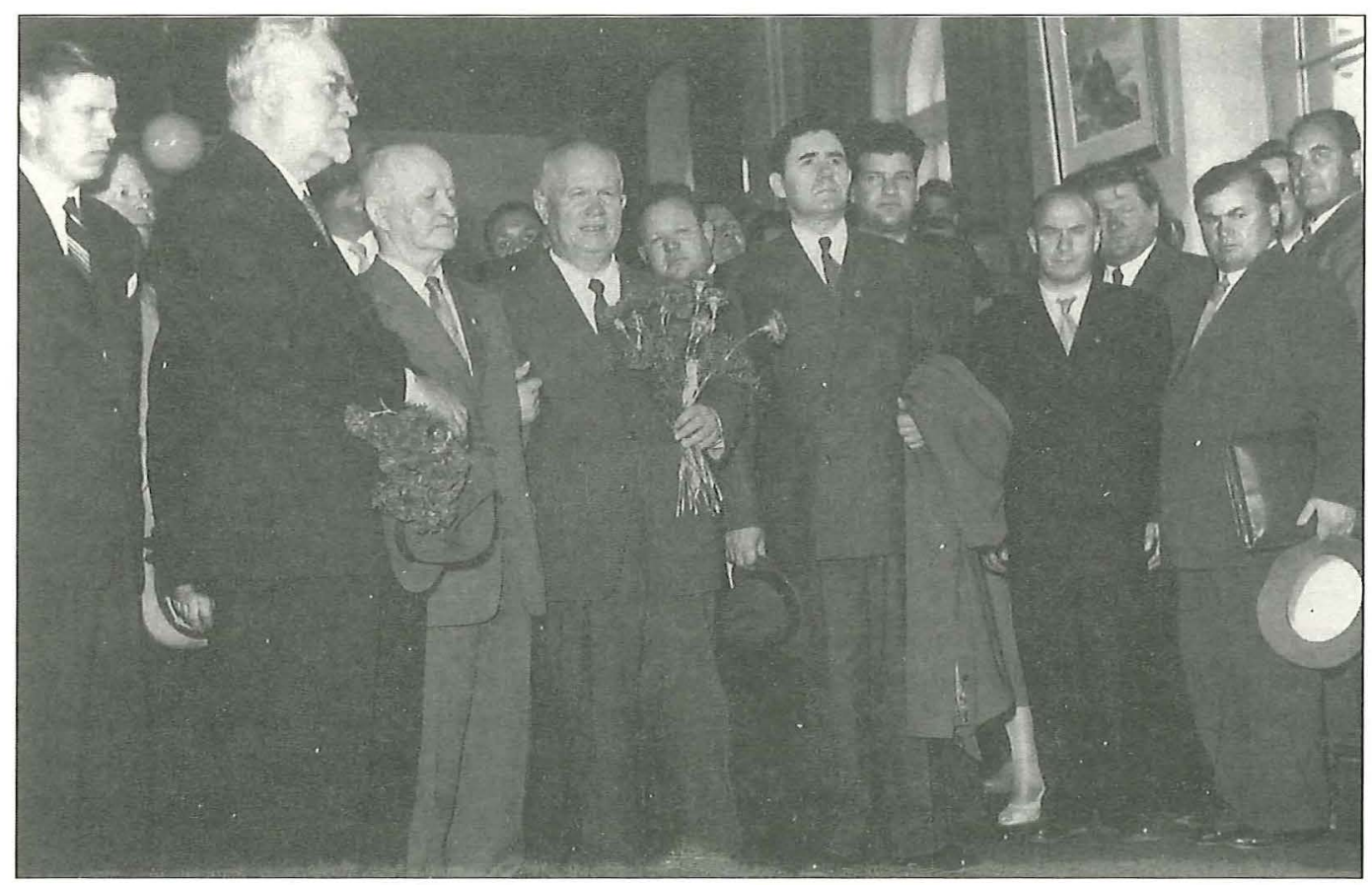

Nikita Crushev and Andre Gromyko in the Lenin Museum, Tampere 12.6.1957.

pated in several party conferences of Russian revolutionaries in Finland. Forced into hiding by the Provisional Government of Russia, Lenin returned to Finland for a couple of months before the October Revolution in 1917 and spent much of the time writing "The State and the Revolution». Lenin's literary activity was, however, interrupted. It was «disturbed» by a political crisis in Russia, the wave of the October Revolution. Lenin was only too glad to be disturbed in such a way: "More pleasant and useful than writing about revolution is making revolution.» The desk at which he worked during that stay, other furniture from the Helsinki flat where Lenin lived and even his walking stick occupy a corner of one room in the Lenin Museum.

\section{THE MEANING OF THE LENIN MUSEUM}

Speaking on the occasion of the museum's 50th anniversary on January 20th 1996, Claes Andersson, the Finnish Minister of Culture, paid tribute to its historical meaning. The passing of the Soviet era into history has only served to augment the importance of Finland's Lenin Museum as a commemoration of that time. The Lenin Museum has an important duty to record, investigate and express through special exhibitions, documents and objects the world of ideas as well as the world of symbols of Lenin's era. The importance of that work is emphasized by the fact that elsewhere Lenin museums have been closed and that their collections are in great 
danger of being destroyed. The Minister of Culture mentioned that the opening of Russian archives and files has offered new opportunities for improving the exhibitions in the museum.

The chairman of the Lenin Museum's board, Professor Olli Vehviläinen of the University of Tampere, pointed out that the founding of the museum in 1946 was closely connected with the new foreign policy which, after losing the war, Finland adopted in the new political situation. At first the visitors to the Lenin Museum were mainly Soviet tourists. "Time went by and the world changed. The USSR collapsed and the Soviet tourists vanished. But the interest in the Lenin Museum increased".

The director of the Tampere city museums, Toimi Jaatinen, noted that in

Exhibition "Cult Lenin» 1990.

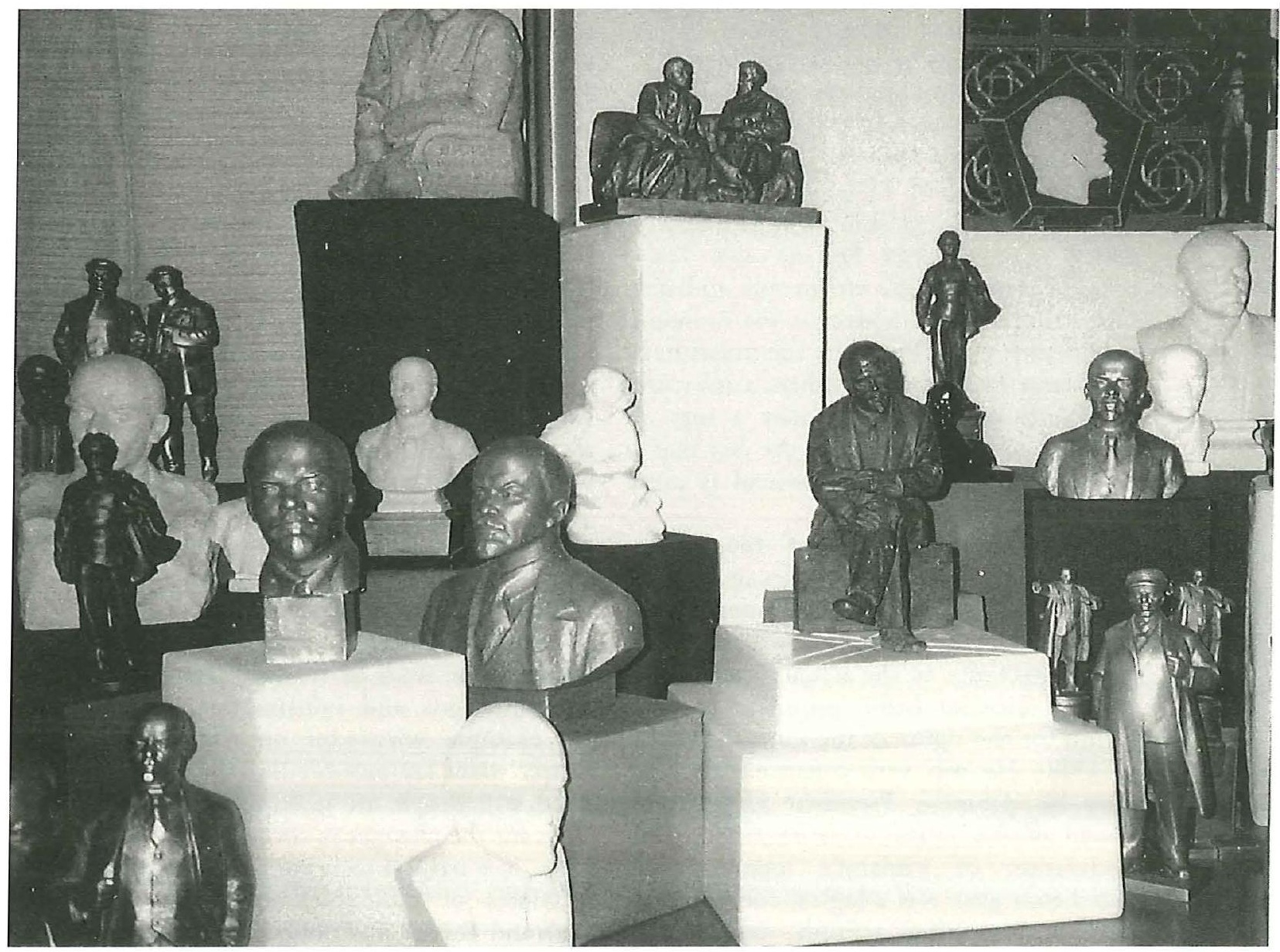


136 many museums like the Lenin Museum which concentrate on one person, visitors find a unique, even spiritual way to get close to a person whom they revere. A place where you can imagine being on the very spot where he or she stood decades or centuries ago, is extremely exciting. Often even the most modest of the original objects are more important than any other parts of the exhibition. Herein lies the unbelievable power of the museum. Herein also lies the unbelievable power of the Lenin Museum. It is THE PLACE. Every city, every country needs places where history can be touched in this way.

The Lenin Museum tells about the life of a person who had a great effect on world history and especially on the history of an independent Finland. Thus at the same time it tells us about a world history which once touched Finland and Tampere. Of course, different people and different decades will appreciate the museum in different ways. For some the museum is the Lenin Museum, for others a museum of an ideology, for yet others a sort of museum of museums where the fact that a Lenin Museum exists in general is even more interesting.

The special meaning of the Lenin Museum for Finnish people lies in the fact that the history of Finland's independence is so closely associated with Lenin's political actions. In the actual locale of the present museum Lenin promised to take action for the rights of the Finnish people in 1906 . He was very consistent in keeping his promise. President Urho Kekkonen alluded to this event in 1970: «The declaration of Finland's independence that Lenin gave was a logical consequence of Lenin's positive attitude towards the
Finns' efforts to disengage themselves from the grips of the Tsarist power.» (Soviet Union - magazine 1/1970).

President Mauno Koivisto said that he still holds the opinion he put forward in 1981 about the meaning of Lenin's national politics to Finland. "The victory of Leninist national politics opened the road to Finnish independence. On the other hand the efforts of the Finns to defend their autonomy and later independence partly supported the revolutionary movement, for example by giving Lenin and the other Bolsheviks shelter and other help.» (Mauno Koivisto. Two periods I. Recollections and notes 1982-1994, p.26).

\section{THE FUTURE OF THE LENIN MUSEUM}

Predicting the future in traditional ways has become even more difficult than before. Rapid changes in society have increased the importance of museums. People want to have solid ground under their feet. They want to understand what is happening around them. The museums can help them understand historical processes.

The extensive changes in society in recent years have also meant a total change in the environment of the Lenin Museum. It can be seen in the re-orientation of the museum, the new strategic visions, new ways of working, new kinds of exhibitions and information policies, for example www-sites on the Internet (http://www. tampere.fi/culture/lenin/ lenina1.htm). People are looking for explanations for the changes in social life. In principle, it is natural to bring Lenin up again in times of radical change in society. Bertrand Russel mentioned, after meeting 


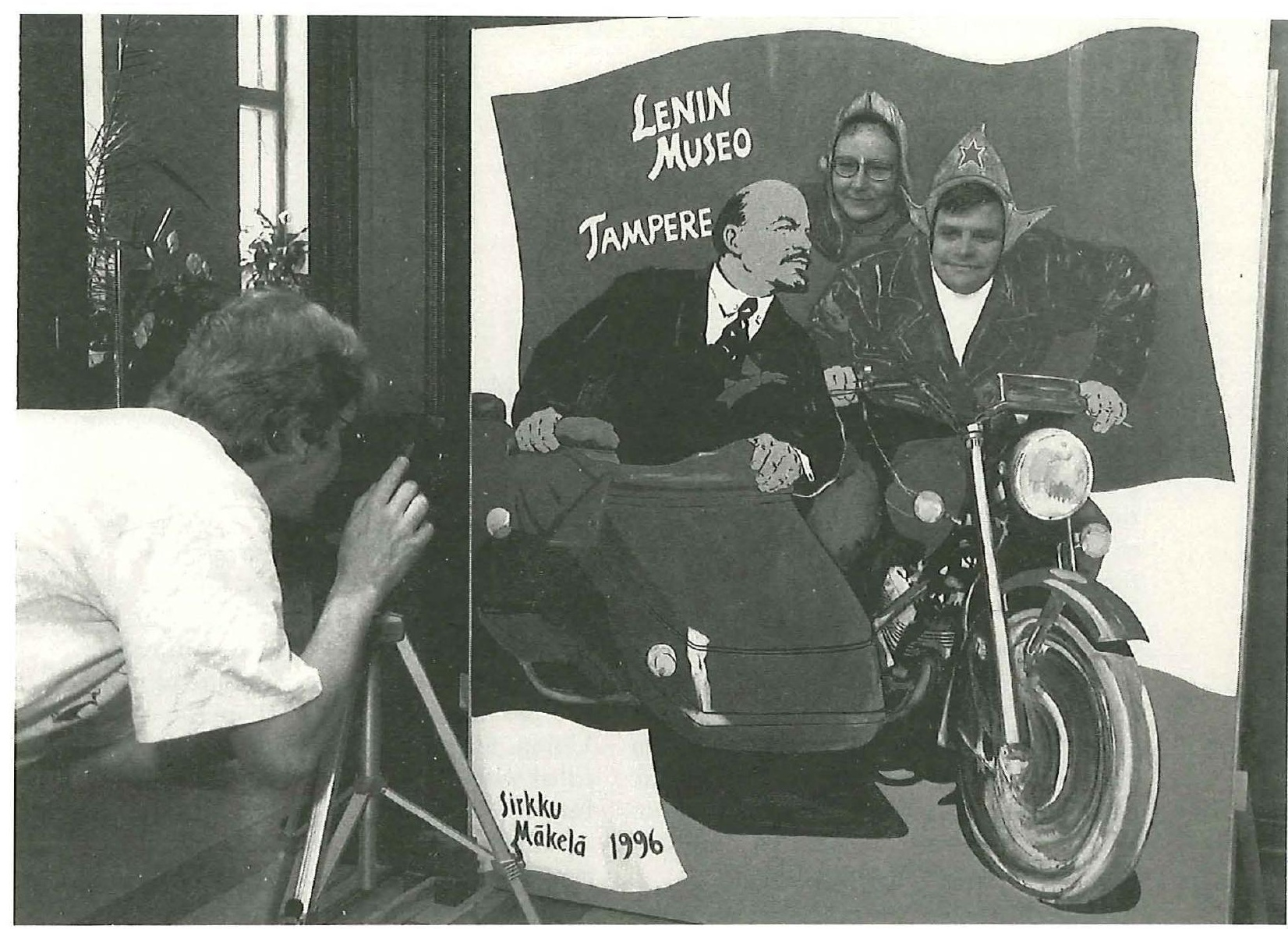

Tintamarresque in the Lenin Museum 1996.

Lenin in 1920, that this century will be the century of Lenin and Einstein.

Many old attitudes, ideas and shared experiences are also vitally influenced by the new points of view and developments. The museum can give people material and ideas for forming their own attitudes towards the changes in the world. Even wrong answers from the past can teach people today. The museum serves as a bridge between history and the present, between yesterday and today. The understanding of history helps us to understand the present and the chances of the future. In this context, the demand for information is clearly visible in the Lenin Museum.

"The times they are a'changing", and these times are full of surprises. The growing popularity of the Lenin Museum may also be a surprise. Behind this lies a very active effort on the part of the museum to find ways of interacting with changes in the environment. Fortunately, the Finnish attitude towards museums is rather tolerant, but museums can always work better to further tolerance, for example by organizing various exhibitions and conferences. The discussion about the Lenin Museum has shown that a museum is a refuge for history. During revolutions, wars and basic changes in society history and its artefacts are in danger of destruction. In such circumstances museums must work actively and uncompromisingly. The Lenin Museum has practical experience in this respect. One crucial question is the relationship between museums and the ruling political power.

A museum which does not change and live, is a cemetery of artefacts. It is dead. We can cross conventional boundaries in many different ways - by opening the museum for churches, beer drinking clubs, businessmen. The possibilities ope- 
138 ned up by social change can be utilized, for example, to improve traditional ways of working and thinking, to find new points of view regarding ordinary conditions and events. A museum can be linked to schools, theatres, the opera, libraries, funfairs, universities, circuses, congresses, archives, TV, radio and newspapers. It can create a network of cultural institutions which can co-operate. And nowadays it is even easier by the Internet. A museum can collect and show a variety of items from photos to movies, from stamps to posters, from pins to locomotives. Feedback from visitors encourages a creative attitude towards the future of the museum.

The revolution in information technology has brought the telephone and fax which have become important tools in museum work. In the near future computers, multimedia, the Internet and other information nets will become more important. The museum will help people to understand the change from things to phenomena. Hundreds of people are already visiting the Internet sites of the Lenin Museum, our virtual museum.

The journalist Simopekka Virkkula has written how one undoubtedly experiences a certain sense of maturity sitting in the shade of Lenin's head. Lenin and his ideas can be understood in the context of their time, the time of industrialism, workers' movements, socialist and communist ideologies. And they can also be made into a certain carnival, appropriated with cheerful nostalgia. Humanity can leave the past with a smile. One can laugh at one's old suits and ideas. The Finnish rock band the Leningrad Cowboys has succeeded in this particularly well. Nowadays the band has its own museum in Helsinki. A Lenin por- trait with an exaggerated, conical quiff, the group's logo, adorns everything from young people's T-shirts to beercan labels.

At the Lenin Museum a special exhibition is now being shown: «Soviet design the home museum of Rosa Liksom». A famous Finnish writer Rosa Liksom says about her collection that she bought her first Soviet things in 1972 in Murmansk. It happened on her first trip abroad when she became very interested in the Soviet Union. She had in her house two cabinets filled with Soviet objects. Later she had to buy more cabinets to house them, and soon her home was so full of Soviet things that she could not even live there herself. She rented a small flat in Helsinki and moved her Soviet souvenirs there. Afterwards she donated the collection to the Lenin Museum.

She was especially interested in the innocent style and the ugly beauty of the objects. In the shops in the Soviet Union tin soldiers or tooth paste could be found next to food. The colours of toys and packets were very strange and she was attracted by that. Many packets of matches and tea were influenced by the beauty of constructivism.

Now those items belong to the museum. They have vanished even from Russian everyday life. The western-style market economy has destroyed those things. One can marvel at them only in the Lenin Museum in Tampere, Finland.

\author{
Aimo Minkkinen, Ph.D. Director of the Lenin \\ Museum \\ Adr. Hämeenpuisto 28, FIN-33200, Finland \\ Fax $+358-032146765$
}

